\title{
STUDI KOMPARATIF MODEL PEMBELAJARAN TALKING STICK DAN SNOWBALL THROWING TERHADAP HASIL BELAJAR TEKNOLOGI INFORMASI DAN KOMUNIKASI (TIK) SISWA KELAS XI SMA NEGERI 1 SERIRIT TAHUN AJARAN 2015/2016
}

\author{
Ni Made Dwi Antari ${ }^{1)}$, Ketut Agustini'2), Dewa Gede Hendra Divayana3) \\ ${ }^{1}$ Fakultas Teknik dan Kejuruan, Universitas Pendidikan Ganesha (penulis 1) \\ email: 1215051038@undiksha.ac.id \\ ${ }^{2}$ Fakultas Teknik dan Kejuruan, Universitas Pendidikan Ganesha (penulis 2) \\ email: ketutagustini@undiksha.ac.id \\ ${ }^{3}$ Fakultas Teknik dan Kejuruan, Universitas Pendidikan Ganesha (penulis 3) \\ email: hendra.divayana@undiksha.ac.id
}

\begin{abstract}
Abstrak
Pembelajaran TIK hendaknya dapat menyiapkan kondisi yang mendukung agar aktivitas dan kreativitas siswa memperoleh pengetahuan sendiri melalui proses belajar. Pemilihan model pembelajaran yang tepat sesuai karakteristik siswa akan membantu keberhasilan suatu pembelajaran. Penelitian studi komparatif akan membandingkan dua model pembelajaran, untuk mengetahui model manakah yang lebih baik. Tujuan penelitian ini untuk mengetahui(1) Pengaruh hasil belajar TIK siswa kelas XI di SMA Negeri 1 Seririt dengan menggunakan model pembelajaran Talking Stick dan Snowball Throwing, (2) Hasil belajar yang lebih tinggi antara model pembelajaran Talking Stick atau Snowball Throwing, (3) respon siswa terhadap penerapan model pembelajaran Talking Stick dan Snowball Throwing.

Jenis penelitian ini adalah eksperimen semu dengan rancangan Post Test Only With Non Equivalent Control Group Design. Pengumpulan data dilakukandenganmetodetespilihangandauntukmengukurranahkognitifdanujiketerampil anuntukranahPsikomotor. Data hasilbelajardianalisismelaluiujiprasyarat yaitu uji normalitas dan homogenitas dengan hasil ketiga kelompok berdistribusi normal dan homogen, dilanjutkan dengan ujihipotesismenggunakan Anova Satu jalur lalu dilanjutkan dengan uji berpasangan $t$-Scheffe.

Hasil uji anova satu jalur menyatakan terdapat pengaruh yang signifikan dalam penggunaan model pembelajaran Talking Stick, Snowball Throwing, dan konvensional. Karena terdapat pengaruh yang signifikan maka dilanjutkan dengan uji $t$-Scheffe dengan hasil terdapat perbedaan yang signifikan antara masing-masing pasangan. Kemudian dilihat dari rata-rata hasil belajar disimpulkan bahwa model pembelajaran Talking Stick lebih baik dengan rata-rata hasil belajar yang lebih tinggi. Sedangkanuntukresponmenggunakanmetodeangket. Hasil analisis angket model Talking Stick diketahui $36 \%$ respon sangat positif, $61 \%$ respon positif dan $3 \%$ respon cukup positif. Sedangkan untuk model Snowball Throwing diketahui 25\% respon sangat positif, $67 \%$ respon positif dan $8 \%$ respon cukup positif.
\end{abstract}

Kata kunci: Studi Komparatif, TIK, Talking Stick, Snowball Throwing, hasil belajar, dan respon siswa

\footnotetext{
Abstract

TIK learning must have to prepared student's activities and creativities to obtained the own knowledge by means of learning process. An appropriate learning model election agree with students characteristics would help an success learning. The comparative study research would have to compared both of learning model, to know which model was better. This research aimed to know (1) The influenced about the result of students' TIK study used Talking stick and Snowball Throwing learning model (2) the highest result of study between Talking stick and Snowball Throwing
} 
learning model (3) the students' response toward Talking stick and Snowball Throwing learning model application.

Kind of this research was quasi experiment by Post Test Only with Non Equivalent Control Group Design. The data accumulation done by multiple choice tests to measured cognitive domain and skill test to psychomotor domain. The students' result study analyzed by prerequisite test was normality test and homogeneity by the result of the three group which normal distribution and homogeneous, continued by hypothesis test used a strip Anova then continued by tSheffe

The result of one way onova exist a significance influenced on the used of Talking Stick leaarning model, Snowball Throwing and conventional. Because of thee was a significance difereences between each partner. Afterwards, seen from the result average of study can be concluded the Talking Stick learning model better than the higest result average of study. Meanwhile, the respond of used questionnaire method, the result of Talking stick model questionnaire known $36 \%$ very positive responses, $61 \%$ positive responses and $3 \%$ positive sufficient responses. Then, Snowball Throwing model known $25 \%$ very positive responses, $67 \%$ positive responses, and $8 \%$ positive sufficient responses.

Keywords : The Comparrative Study, TIK, Talking stick, Snowball Throwing, the study result, students' respond

\section{PENDAHULUAN}

Mata Pelajaran TIK bertujuan untuk mempersiapkan peserta didik agar mampu mengantisipasi perkembangan teknologi yang semakin pesat (Arianti, N. K., 2013).

Tujuan mata pelajaran TIK lainnya yaitu agar siswa dapat menggunakan perangkat TIK secara cepat dan optimal untuk mendapatkan dan memproses informasi dalam kegiatan belajar, bekerja dan aktivitas lainnya, sehingga siswa mampu berkreasi, mengembangkan sikap inisiatif, mengembangkan kemampuan eksplorasi mandiri dan mudah beradaptasi dengan perkembangan baru. $\mathrm{Hal}$ ini menunjukkan bahwa mata pelajaran TIK termasuk salah satu mata pelajaran penting pada kurikulum KTSP yang dikenalkan kepada siswa (Dewi, A. A., 2013).

SMA N 1 Seririt adalah salah satu sekolah yang masih menerapkan kurikulum KTSP dan TIK sebagai salah satu mata pelajaran penting dalam kurikulum KTSP. Berdasarkan catatan nilai yang dimiliki oleh guru TIK di SMA Negeri 1 Seririt terlihat bahwa nilai TIK siswa dari tahun ke tahun belum mampu mencapai KKM.

Pembelajaran TIK hendaknya dapat menyiapkan kondisi yang mendukung agar aktivitas dan kreativitas siswa untuk memperoleh pengetahuan sendiri melalui proses belajar. Inovasi model pembelajaran akan membantu proses pembelajaran karena model pembelajaran disesuaikan dengan keadaan siswa dan materi yang disajikan. Berbagai model, metode dan strategi telah dilakukan untuk melakukan perbaikan dalam proses pembelajaran. Menurut Nur dalam Lisdayanti, menyatakan bahwa model pembelajaran kooperatif (cooperative learning) merupakan "teknik-teknik kelas praktis yang dapat digunakan guru setiap hari untuk membantu siswa belajar setiap mata pelajaran, mulai dari keterampilan dasar sampai memecahkan masalah yang kompleks. Menurut Trianto dalam Lisdayanti Pembelajaran kooperatif bukanlah sesuatu yang baru. Siswa akan dibentuk dalam kelompok - kelompok yang terdiri dari 4 atau 5 orang untuk bekerja sama dalam menguasai materi yang diberikan guru. Tujuan dibentuknya kelompok tersebut adalah untuk memberikan kesempatan kepada semua siswa untuk dapat terlibat secara aktif dalam proses berpikir dan kegiatan belajar (Lisdayanti, N. P., 2014).

Terdapat model pembelajaran kooperatif lainnya yang menuntut siswa agar aktif dalam proses pembelajaran yaitu model pembelajaran Talking Stick dan Snowball Throwing. Keduan model tersebut menuntut siswa siap untuk menerima pertanyaan yang diajukan oleh teman atau guru. Ketidaktahuan siswa 
kapan dia akan mendapatkan pertanyaan akan memacu siswa untuk belajar dan mempersiapkan diri untuk menjawab apabila nanti tongkat pada model pembelajaran Talking Stick dan kertas pada model pembelajaran Snowball Throwing akan sampai pada dirinya. Kedua model ini dikemas seperti permainan agar menarik bagi siswa.

Hanya saja kedua model tersebut memiliki perbedaan pada proses kegiatan inti dimana pada model pembelajaran Talking Stick siswa yang memegang tongkat akan mendapatkan pertanyaan dari guru, sedangkan model pembelajaran Snowball Throwing pertanyaan akan bersumber dari siswa dan dijawab kembali oleh siswa. Sehingga penulis ingin mengetahui perbandingan model pembelajaran antara model pembelajaran Talking Stick dengan model pembelajaran Snowball Throwing, sehingga dilakukan kegiatan perbandingan untuk mengetahui manakah yang lebih baik diterapkan.

\section{Teori Belajar}

Pengertian belajar menurut Bower dan Hilgard dalam Suwitrabahwa belajar mengacu pada perubahan prilaku atau potensi individu sebagai hasil dari pengalaman dan perubahan tersebut tidak disebabkan oleh instink, kematangan atau kelelahan dan kebiasaan. Ciri-ciri belajar adalah (1) Belajar harus memungkinkan terjadinya perubahan prilaku pada diri individu, (2) Pengalaman itu harus merupakan buah dari pengalaman, (3) Perubahan itu relatif menetap.

Teori belajar Behavioristik merupakan perubahan tingkah laku hasil interaksi antara stimulus dan respon yaitu proses manusia untuk memberikan respons tertentu berdasarkan stimulus yang datang dari luar. Teori belajar behavioristik sangat menekankan pada hasil belajar ("outcome"), yaitu perubahan tingkah laku yang dapat dilihat, dan tidak begitu memperhatikan apa yang terjadi di dalam otak manusia karena hal tersebut tidak dapat dilihat.

Teori Konstruktivisme ialah salah satu teori belajar, teori ini memandang bahwa siswalah yang aktif menata, merevisi pengetahuan lama yang tidak sesuai, dalam hal ini menganut pembelajaran dikelas guru membantu siswa menemukan fakta, konsep, prinsip dan prosedur siswa itu sendiri, bukan memberikan ceramah atau mengendalikan seluruh kegiatan kelas (Suwatra et.al., 2007).

\section{Model Pembelajaran Talking Stick}

Model pembelajaran Talking Stick merupakan satu dari sekian banyak satu model pembelajaran kooperatif.

Model Pembelajaran Talking Stick dilakukan dengan berbantuan tongkat. Tongkat dijadikan jatah atau giliran untuk berpendapat atau menjawab pertanyaan dari guru setelah siswa mempelajari materi pelajaran. Model pembelajaran Talking Stick sangat cocok diterapkan khususnya pada siswa-siswa SD, SMP, dan SMA/SMK. Selain sebagai metode agar siswa mau berpendapat, tetapi juga untuk melatih siswa berani berbicara. Dengan model pembelajaran ini suasana kelas bisa terlihat lebih hidup dan tidak monoton.

Talking Stick (tongkat berbicara) sebenarnya istilah yang sudah berumur panjang. Karena metode ini berawal dari kebiasaan penduduk asli Amerika untuk mengajak semua orang berbicara atau menyampaikan pendapat dalam suatu forum (pertemuan antar suku). Dan karena perkembangan informasi dan teknologi, model ini diadobsi untuk dipergunakan dalam sistem pembelajaran disekolahsekolah.

Sintak pembelajaran model pembelajaran Talking Stickadalah sebagai berikut: (1) Guru menjelaskan tujuan pembelajaran, (2) Guru membentuk kelompok yang terdiri atas 5 orang, (3) Guru menyiapkan sebuah tongkat yang panjangnya $20 \mathrm{~cm}$, (4) Guru menyampaikan materi pokok yang akan dipelajari, kemudian memberikan kesempatan para kelompok untuk membaca dan mempelajari materi pelajaran tersebut dalam waktu yang telah ditentukan, (5) Siswa berdiskusi membahas masalah yang terdapat didalam wacana, (6) Setelah kelompok selesai membaca materi pelajaran dan mempelajari isinya, guru mempersilahkan 
anggota kelompok untuk menutup isi bacaan, (7) Guru mengambil tongkat dan memberikan kepada salah satu anggota kelompok yang memegang tongkat tersebut harus menjawabnya, demikian seterusnya sampai sebagian besar siswa mendapat bagian untuk menjawab setiap pertanyaan dari guru, (8) Siswa lain boleh membantu menjawab pertanyaan jika anggota kelompoknya tidak bisa menjawab pertanyaan, (9) Setelah semuanya mendapat giliran, guru membuat kesimpulan dan melakukan evaluasi, baik individu ataupun secara berkelompok. Dan setelah itu menutup pelajaran.

Keunggulan model pembelajaran Talking Stick menurut Kuriasih \& Sani antara lain sebagai berikut: (1) Menguji kesiapan siswa dalam penguasaan materi pembelajaran, (2) Melatih membaca dan memahami dengan cepat materi yang telah disampaikan., (3) Agar lebih giat belajar karena siswa tidak pernah tau tongkat akan sampai pada gilirannya (Kurniasih, \& Sani, 2015).

Model ini sangat cocok diterapkan dalam Kurikulum Tingkat Satuan Pendidikan (KTSP) dimana siswa dituntut lebih aktif dalam proses pembelajaran (Pranata, P. A., 2013).

\section{Model Pembelajaran Snowball Throwing}

Menurut Komalasari dalam Susanti(2013) "Model Pembelajaran Snowball Throwing adalah model pembelajaran yang menggali potensi kepemimpinan siswa dalam kelompok dan keterampilan membuat serta menjawab pertanyaan yang dipadukan melalui suatu permainan imajinatif membentuk dan melempar bola salju". Model pembelajaran Snowball Throwing menggunakan bola pertanyaan dari kertas yang digulung bulat berbentuk bola, yang kemudian dilempar secara bergiliran diantara sesama anggota kelompok (Susanti, K. A., 2013).

Apabila proses pembelajaran ini berjalan lancar, maka akan terbentuklah suasana kelas yang dinamis, karena kegiatan siswa tidak hanya berpikir, menulis, bertanya, atau berbicara. Tetapi mereka juga melakukan aktivitas fisik yaitu menggulung kertas dan melemparkannya pada siswa lain. Dengan demikian, tiap anggota kelompok akan mempersiapkan diri karena pada gilirannya mereka harus menjawab pertanyaan dari temannya yang terdapat dalam bola kertas. Model ini juga memberikan pengalaman kepada siswa untuk mengembangkan keterampilan menyimpulkan isi berita atau informasi yang mereka peroleh dalam konteks nyata dan situasi yang kompleks.

Menurut Johar dalam Aditya (2013) Proses pembelajaran yang baik hendaknya menempatkan siswa sebagai pencari ilmu sehingga perlu dibiasakan memecahkan dan merumuskan sendiri hasilnya. Pada model pembelajaran Snowball Throwing memberikan pengalaman kepada siswa untuk mengembangkan keterampilan menyimpulkan isi berita atau informasi yang mereka peroleh dalam konteks nyata dan situasi yang kompleks (Aditya, K. M. 2013).

Beberapa ciri-ciri dari metode pembelajaran Snowball Throwing adalah: (a) Setiap anggotanya memiliki peranan, (b) terjadi hubungan interaksi langsung diantara siswa, (c) setiap siswa membuat pertanyaan dalam lembar kertas kerja yang dibentuk seperti bola, (d) pertanyaan yang dibentuk seperti bola dilempar dan ditangkap dari siswa yang satu ke siswa yang lain, (e) menjawab pertanyaan dari lemparan pertanyaan yang berbentuk bola (Aditya, K. M., 2013). Keunggulan dari model pembelajaran Snowball Throwing adalah (a) Melatih kesiapan siswa, (b) Saling memberikan pengetahuan.

Sintak model pembelajaran Snowball Throwin adalah sebagai berikut: (1) Guru menyampaikan materi yang akan disajikan, (2) Guru membentuk kelompok, (3) Siswa berdiskusi dengan anggota kelompok mengenai materi yang disajikan, (4) Siswa menuliskan pertanyaan pada satu lembar kerja yang menyangkut materi yang sudah dijelaskan, (5) Siswa melempar bola kertas pertanyaan kepada siswa lain, (6) Siswa mendapat satu bola kertas pertanyaan dan siswa diberikan kesempatan untuk menjawab pertanyaan yang ia dapatkan secara bergantian, (7) 
Guru menarik kesimpulan, melakukan evaluasi dan menutup pembelajaran.

\section{Hasil Belajar}

Menurut ahli psikologi pendidikan dalam Wirawan pengertian belajar secara psikologis merupakan "suatu proses perubahan yaitu perubahan tingkah laku sebagai hasil interaksi dengan lingkungan dalam memenuhi kebutuhan hidupnya". Pendapat lain juga dikemukakan oleh Sardiman dalam Wirawan, bahwa "belajar boleh dikatakan juga sebagai suatu proses interaksi antara diri manusia dengan lingkungannya, yang mungkin berwujud pribadi, fakta, konsep ataupun teori" (Wirawan, D. N., 2013).

Berdasarkan dua pendapat yang dikemukakan diatas dapat disimpulkan bahwa belajar merupakan proses interaksi manusia dengan lingkungan, dimana seluruh panca indera manusia ikut berperan dan diperlukan proses sosialisasi guna memenuhi kebutuhan hidupnya.

Selanjutnya, hasil belajar diartikan sebagai kemampuan maksimal yang dicapai seseorang dalam suatu usaha yang menghasilkan pengetahuan atau nilai-nilai kecakapan. Pendapat lain juga dikemukakan oleh Sudjana dalam Maindra (2013), yaitu hasil belajar adalah kemampuan-kemampuan yang dimiliki siswa setelah ia menerima pengalaman belajarnya. Berdasarkan pendapat diatas dapat disimpulkan bahwa hasil belajar adalah suatu kemampuan siswa yang dapat diukur dan merupakan bukti penguasaan ilmu pengetahuan selama mengikuti pembelajaran disekolah (Maindra, N. K., 2013).

\section{METODE}

Penelitian Eksperimen ini memiliki tujuan untuk mengetahui model manakah yang lebih baik diantara model pembelajaran Talking Stick, model pembelajaran Snowball Throwing dan model pembelajaran konvensional siswa kelas XI pada mata pelajaran TIK di SMA Negeri 1 Siririt.

Metode yang digunakan dalam penilitian ini adalah metode eksperimen dengan membagi 3 kelompok yang terdiri dari 1 kelompok kelas control dan 2 kelompok kelas eksperimen. Kelompok kelas kontrol merupakan kelompok kelas yang akan diterapkan model pembelajaran langsung. 2 kelompok kelas eksperimen terdiri dari kelompok pertama dan kelompok kedua. Kelompok pertama adalah kelompok yang belajar menggunakan model pembelajaran Talking Stick. Kelompok kedua adalah kelompok yang belajar menggunakan model pembelajaran Snowball Throwing. Jenis penelitian eksperimen yang digunakan yaitu penelitian eksperimen semu (quasi experiment). Desain penelitian yang digunakan adalah posttest with non equivalent control group design.

Metode pengumpulan data yang digunakan dalam penelitian ini adalah metode tes dan angket. Metode tes digunakan untuk mengetahui hasil belajar TIK siswa dengan menggunakan tes pilihan ganda (obyektif) dan tes keterampilan (psikomotor), sedangkan metode angket digunakan untuk mengetahui respon siswa terkait dengan penerapan model pembelajaran Talkinh Stick dan responsiswa terhadap model pembelajaran Snowball Throwing. Uji prasyarat yang digunakan dalam penelitian ini yaitu uji normalitas dilakukan untuk mengetahui sebaran data tersebut normal atautidak normal terhadap hasil belajar TIK pada kelas eksperimen dan kelas kontrol dan uji homogenitas dilakukan untuk mengetahui apakah varians kelompok eksperimen dan kelompok kontrol homogen atau tidak homogeny sedangkan uji hipotesis dilakukan untuk mengetahui apakah hipotesis alternatif yang telah diajukan diterima atau ditolak dengan menggunakan rumus Anova Satu Jalur dan uji berpasangan $t$-scheffe.

\section{HASIL DAN PEMBAHASAN}

Data penelitian dari 109 anggota sampel yang terdiri dari 36 siswa dikelas eksperimen dengan model pembelajaran Talking Stick, 36 siswa dikelas eksperimen model pembelajaran Snowball Throwing dan 37 siswa dikelas kontrol, didapatkan hasil bahwa rata-rata posttest hasil belajar TIK yang dicapai siswa pada kelompok 
eksperimen dengan model pembelajaran Talking Stick adalah 43,53, rata-rata posttest pada kelompok eksperimen dengan model pembelajaran Snowball Throwing adalah 40,67 sedangkan ratarata posttest untuk kelompok kontrol adalah 33,62. Dengan demikian, rata-rata posttest hasil belajar TIK pada kelompok eksperimen dengan model pembelajaran Talking Stick lebih besar dibandingkan dengan kelas eksperimen dengan model pembelajaran Snowball Throwing ataupun kelas kontrol.

Perhitungan normalitas dan homogenitas ketiga kelas memiliki data yang normal dan homogen, berdasarkan uji normalitas yang telah dilakukan, diperoleh bahwa distribusi data dari ketiga kelas normal, dimana hasil perhitungan pada kelas eksperimen dengan model pembelajaran Talking Stick memperoleh $\mathrm{X}^{2}$ hitung sebesar4,537, pada kelas eksperimen dengan model pembelajaran Snowball Trowing memperoleh $\mathrm{X}^{2}{ }_{\text {hitung }}$ sebesar 1,874 sedangkan pada kelas kontrol memperoleh $X^{2}$ hitung sebesar 1,252 dengan $\mathrm{X}^{2}$ tabel sebesar7,815, karena $\mathrm{X}^{2}$ hitung dari ketiga kelas lebih kecil dari $X^{2}$ tabel maka dapat dinyatakan bahwa distribusi data dari kedua kelas normal. Sedangkan dari uji homogenitas yang telah dilakukan diperoleh bahwa varians antara kelas eksperimen model pembelajaran Talking Stick, model pembelajaran Snowball Throwing dan kelas control homogen, dimana diperoleh nilai $F_{\text {hitung }}$ sebesar 1,56, dengan $F_{\text {tabel }}$ sebesar 1,80 , karena nilai $F_{\text {hitung }}$ lebih kecil dari $F_{\text {tabel }}$ maka dapat dinyatakan bahwa varians dari ketiga kelas homogen.

Setelah diketahui bahwa sebaran data pada kedua kelas normal, kemudian varians dari kedua kelas homogeny, maka dilakukan pengujian hipotesis menggunakan rumus Anova Satu Jalur dengan taraf signifikan $5 \%$, dimana dari perhitungan tersebut memperoleh $F_{\text {hitung }}$ sebesar 105,3188 dengan $F_{\text {tabel }}$ sebesar 3,09 , karena $F_{\text {hitung }}$ lebih besar dari $F_{\text {tabel }}$ maka hipotesis alternatif yang telah diajukan diterima yang artinya terdapat pengaruh yang signifikan dalam penerapan model pembelajaran Talking
Stick dan model pembelajaran Snowball Throwing.

Karena hasil uji hipotesis 1 dinyatakan signifikan, maka dilanjutkan dengan uji berpasangan t-sceffe untuk menguji hipotesis kedua yaitu model pembelajaran manakah yang lebih baik diantara Talking Stick dan model pembelajaran Snowball Throwing. Dari hasil perhitungan $F_{\text {hitung }}$ yang dibandingkan dengan $F_{\text {tabel }}$ yang diperoleh dari tabel $F$ dengan $\mathrm{db}$ pembilang $\mathrm{a}-1=2-1=1 \mathrm{dan} \mathrm{db}$ penyebut $(\mathrm{n} 1+\mathrm{n} 2)-\mathrm{a}=(36+36)-2=70$, dimana $F_{\text {tabel }}$ adalah 3,98. Sehingga hasil uji berpasangan t-sceffe untuk kelas eksperimen model pembelajaran Talking Stick dengan kelas eksperimen model pembelajaran Snowball Throwing memperoleh hasil signifikan karena $F_{\text {hitung }}>$ $F$ tabel yaitu $(4,0384>3,90)$, hasil uji berpasangan t-sceffe untuk kelas eksperimen model pembelajaran Talking Stick dengan kelas kontrol memperoleh hasil signifikan karena $F_{\text {hitung }}>F_{\text {tabel }}$ yaitu $(14,0779>3,90)$, dan hasil uji berpasangan t-sceffe untuk kelas eksperimen model pembelajaran Snowball Throwing dengan kelas kontrolmemperoleh hasil signifikan karena $F_{\text {hitung }}>F_{\text {tabel }}$ yaitu $(10,0119>3,90)$.

Setelah diperoleh hasil yang signifikan maka dilanjutkan untuk menentukan model pembelajaran mana yang lebih baik dengan cara membandingkan rata-rata hasil belajar siswa kelas eksperimen model pembelajaran Talking Stick, kelas eksperimen model pembelajaran Snowball Throwing, dan kelas kontrol dengan model pembelajaran konvensional. Dari nilai rata - rata masing masing kelas diperoleh hasil nilai rata-rata kelas eksperimen model pembelajaran Talking Stick adalah 43,5277, nilai rata-rata kelas eksperimen model pembelajaran Snowball Throwing dalah 40,6667, dan nilai ratarata kelas eksperimen model pembelajaran konvensional yang merupakan menjadi kelas kontrol adalah 33,6216 . Sehingga rata-rata kelas eksperimen model pembelajaran Talking Stick lebih besar dari model pembelajaran kelas eksperimen model pembelajaran Snowball Throwing dan lebih besar dari 
kelas kelas kontrol yaitu $(43,5277>$ $40,6944>33,6216)$, sehingga $H_{0}$ ditolak dan $\mathrm{H}_{\mathrm{a}}$ diterima yaitu rata-rata hasil belajar siswa yang menggunakan model pembelajaran Talking Stick lebih tinggi dari pada siswa yang menggunakan model pembelajaran Snowball Throwing Sehingga model pembelajaran Talking Stick lebih baik dibanding model pembelajaran Snowball Throwing.

Model pembelajaran Talking Stick lebih baik dikarenakan pada model pembelajaran ini siswa diarahkan untuk aktif dalam proses pembelajaran. Siswa dibimbing untuk berani mengungkapkan pendapat. Melalui model pembelajaran Talking Stick siswa yang terakhir memegang tongkat akan diberikan pertanyaan oleh guru, sehingga guru akan dapat menilai dari jawaban siswa apakah mereka benar-benar memahami materi yang diajarkan atau tidak. Hal tersebut sesuai dengan kelebihan dari model pembelajaran Talking Stick yaitu menguji kesiapan siswa dalam penguasaan materi (Kurniasih \& Sani, 2015). Pembelajaran dengan model pembelajaran Talking stick juga dikemas dalam bentuk game dengan berbantuan tongkat, siswa terpacu untuk belajar agar bisa menjawab pertanyaan yang diajukan guru karena mereka tidak tahu kapan tongkat akan sampai pada giliran mereka, serta siswa menjadi antusias belajar hal ini sesuai dengan pembahasan penelitian terkaitan bahwa model pembelajaran Talking Stick ini maka siswaakan lebih tertarik dalam mengikuti pembelajaran di dalam kelas.Pranata, P. A. (2013), Pertanyaan yang bersumber dari guru juga mendukung kenapa model pembelajaran ini menjadi lebih baik dibandingkan model pembelajaran Snowball Throwing, karena apabila pertanyaan diberikan oleh guru pembelajaran menjadi terarah, guru dapat mengarahkan siswa dengan pertanyaanpertanyaan yang dapat mengevaluasi kemampuan siswa dan guru dapat mengontrol materi yang dibahas agar tidak melewati batas standar komptennsi dan indikator yang sedang dipelajari.

Sedangkan pada model pembelajaran Snowball Throwing hampir sama dengan model pembelajaran Talking
Stick dimana proses pembelajaran juga dikemas dengan game, dan berkelompok. Model ini juga melatih kesiapan siswa dan saling memberikan pengetahuan (Kurniasih \& Sani, 2015:78), hanya saja pada model ini pertanyaan akan bersumber dari siswa dan dijawab oleh siswa. Namun dari proses yang berlangsung, pertanyaan dari siswa terkadang melampaui batas materi yang dibahas, selain itu ketika penerapan model pembelajaran berkelompok walaupun sudah ditekankan agar seluruh anggota kelompok harus mendapat giliran menjawab, tapi fakta yang ada hanya beberapa siswa saja yang aktif menjawab, dengan alasan teman yang mendapat giliran tidak mengetahui jawabannya sehingga model ini belum mampu membuat seluruh siswa aktif, guru juga harus lebih aktif untuk mengontrol siswa agar semua siswa mau berpartisipasi.

Hasil dari analisis respon siswa kelas eksperimen model pembelajaran Talking Stick adalah sebanyak 13 siswa (36\%) siswa merespon sangat positif akan model pembelajaran Talking Stick, 22 siswa (59\%) siswa merespon positif, 1 siswa (10\%) siswa merespon cukup positif dan tidak ada siswa yang merespon kurang positif dan sangat kurang positif. Dilihat berdasarkan pengamatan peneliti dalam menerapkan model pembelajaran Talking Stick di kelas XI IPA 3, dapat diketahui bahwa siswa sebagian besar tergolong aktif dalam penerapan pembelajaran tersebut. Data diatas divisualisasikan ke dalam bentuk grafik akan tampak seperti Gambar 1.

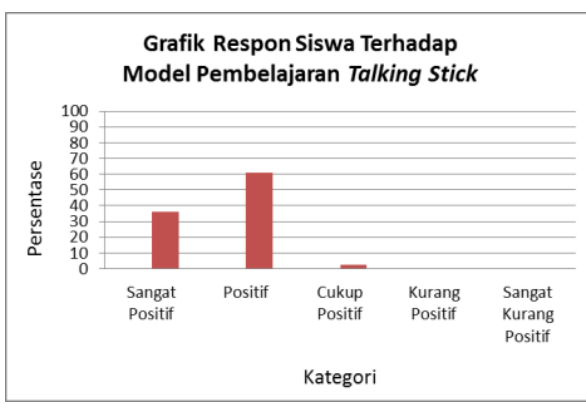

Gambar 1. Grafik Respon Siswa Model Pembelajaran Talking Sti 
Sedangkan hasil analisis respon siswa untuk model pembelajaran Snowball Throwing diketahui bahwa sebanyak 9 siswa (25\%) siswa merespon sangat positif akan model pembelajaran Snowball Throwing, 24 siswa (67\%) siswa merespon positif, 3 siswa (8\%) siswa merespon cukup positif dan tidak ada siswa yang merespon kurang positif dan sangat kurang positif. Dilihat berdasarkan pengamatan peneliti dalam menerapkan model pembelajaran Talking Stick dikelas XI IPA 2, dapat diketahui bahwa siswa sebagian besar tergolong aktif dalam penerapan pembelajaran tersebut. Data diatas divisualisasikan ke dalam bentuk grafik akan tampak seperti Gambar 2.

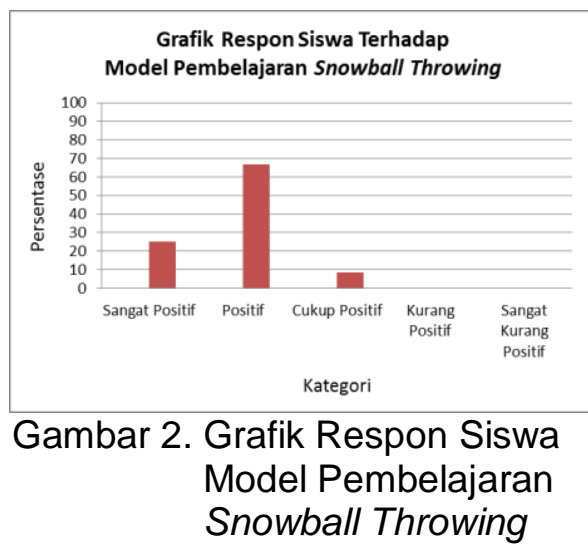

\section{SIMPULAN DAN SARAN}

Berdasarkan rumusan masalah, tujuan penelitian, pengajuan hipotesis dan analisis data penelitian, maka dapat ditarik beberapa simpulan sebagai berikut (1) Terdapat pengaruh yang signifikan terhadap hasil belajar siswa yang menggunakan model pembelajaran Talking Stickdan model pembelajaran Snowball Throwing terhadap hasil belajar TIK siswa kelas XI SMA Negeri 1 Seririt. Hal ini dapat dilihat dari hasil perolehan $\mathrm{F}_{\text {hitung }}=105,3188$ dibandingkan dengan $F_{\text {tabel }}$ dengan taraf signifikan $5 \%$ yaitu 3,09 dan dengan taraf signifikan $1 \%$ yaitu 4,82 . Sehingga $F_{\text {hitung }}>\mathrm{F}$ tabel baik dengan taraf signifikan $1 \%$ maupun $5 \%(105,3188>$ $4,82>3,09$ ) sehingga $\mathrm{H}_{0}$ ditolak dan $\mathrm{H}_{a}$ diterima. Sehingga model pembelajaran Talking Stick dan model pembelajaran Snowball Throwing memberikan pengaruh yang signifikan terhadap hasil belajar siswa, (2) Model pembelajaran Talking Stick lebih baik dari pada model pembelajaran Snowball Throwing. Hal ini dapat dilihat dari uji rata - rata hasil belajar siswa, namun sebelum rata-rata hasil belajar siswa dibandingkan terlebih dahulu dilakukan uji berpasangan t-sceffe untuk mengetahui apakah masing masing pasangan memiliki perbedaan yang signifikan atau tidak sehingga bisa dibandingkan. Hasil dari uji berpasangan tsceffe diperoleh bahwa $F_{\text {hitung }}$ dibandingkan dengan $F_{\text {tabel, }}$ dimana $F_{\text {tabel }}$ adalah 3,98. Sehingga hasil uji berpasangan t-sceffe untuk kelas eksperimen model pembelajaran Talking Stick dengan kelas eksperimen model pembelajaran Snowball Throwing memperoleh hasil signifikan karena $F_{\text {hitung }}>$ $F$ tabel yaitu $(4,0384>3,90)$, hasil uji berpasangan t-sceffe untuk kelas eksperimen model pembelajaran Talking Stick dengan kelas kontrol memperoleh hasil signifikan karena $F_{\text {hitung }}>F_{\text {tabel }}$ yaitu $(14,0779>3,90)$, dan hasil uji berpasangan t-sceffe untuk kelas eksperimen model pembelajaran Snowball Throwing dengan kelas kontrol memperoleh hasil signifikan karena $F_{\text {hitung }}>$ $F$ tabel yaitu $(10,0119>3,90)$. Setelah mendapat hasil yang signifikan Dilihat dari nilai rata - rata masing masing kelas. Sehingga diperoleh rata-rata kelas eksperimen model pembelajaran Talking Stick lebih besar dari model pembelajaran kelas eksperimen model pembelajaran Snowball Throwing dan lebih besar dari kelas kelas kontrol yaitu (43,5277> 40,6944>33,6216), sehingga $H_{0}$ ditolak dan $\mathrm{H}_{\mathrm{a}}$ diterima yaitu Hasil belajar siswa yang menggunakan model pembelajaran Talking Stick lebih tinggi dari pada siswa yang menggunakan model pembelajaran Snowball Throwing Sehingga model pembelajaran Talking Stick lebih baik dibanding model pembelajaran Snowball Throwing, (3) Terdapat respon yang positif dengan pembelajaran menggunakan Model pembelajaran Talking Stick dan model pembelajaran Snowball Throwing. Hal ini dapat dilihat dari rata-rata respon siswa yang menggunakan model pembelajaran Talking Stick yaitu sebesar 
60,19 yang tergolong kategori positif, dan rata-rata respon siswa yang menggunakan model pembelajaran Snowball Throwing yaitu sebesar 57,94 yang tegolong kategori positif. Sehingga penerapan model pembelajaran Talking Stick dan model pembelajaran Snowball Throwing diterima dengan positif oleh siswa.

Dari hasil penelitian yang diperoleh, maka peneliti memberikan saran-saran sebagai berikut guna meningkatkan kualitas pembelajaran TIK : (1) Sebelum menerapkan suatu model pembelajaran, sebaiknya diamati terlebih dahulu karakteristik siswa serta karakteristik materi yang akan diberikan perlakuan untuk mendapatkan hasil yang lebih baik, (2) Peneliti diharapkan mempersiapkan penilaian siswa ketika proses permainan menggunakan model pembelajaran Talking Stick atau model pembelajaran Snowball Throwing dengan baik dan menyiapkan rubrik penilaian dengan baik. (3) Hasil penelitian menunjukkan bahwa siswa yang belajar dengan model pembelajaran Talking Stick memperoleh hasil belajar TIK yang lebih baik daripada siswa yang menggunakan model pembelajaran Snowball Throwing dan model pembelajaran konvensional. Oleh karena itu, penulis menyarankan kepada para guru bahwa model pembelajaran Talking Stick dapat digunakan sebagai salah satu alternatif model pembelajaran yang sesuai dengan paradigma KTSP, (4) Peneliti menyadari bahwa perlakuan yang diberikan keapada siswa cukup singkat jika digunakan untuk mengetahui hasil belajar siswa. Hal ini disebabkan karena peneliti hanya meneliti 1 bab saja yaitu dokumen pengolah angaka dengan variasi teks dan tabel yang berlangsung 5 kali pertemuan ( $5 \times 2$ jam pelajaran) yang dirasa singkat untuk mengetahui secara rinci hasil belajar siswa. Ada kemungkinan pokok bahasan lain akan memberikan hasil yang berbeda dengan pokok bahasan yang dijadikan materi perlakuan. Disarankan penelitian lain agar melaksanakan penelitian sejenis dengan pemilihan materi yang berbeda dan waktu yang lebih lama untuk mendapatkan hasil belajar siswa yang lebih rinci.

\section{DAFTAR PUSTAKA}

Arianti, N. K. (2013). Pengaruh Model Pembelajaran Make A Match Untuk Meningkatkan Hasil Belajar Dalam Pembelajaran TIK Kelas VIII I Semester Ganjil Tahun Ajaran 2012/2013 Di SMP Negeri 5 Singaraja. Universitas Pendidikan Ganesha.

Dewi, A. A. (2013). Pengaruh Penerapan Pembelajaran Discovery Strategy Terhadap Hasil Belajar Kognitif Pada Mata Pelajaran Teknologi Informasi Dan Komunikasi (TIK) Siswa Kelas XI SMA N 1 Gianyar Tahun Ajaran 2012/2013. Universitas Pendidikan Ganesha.

Lisdayanti, N. P. (2014). Pengaruh Model Pembelajaran Kooperatif Talking Stick Berbantuan Media Gambar Terhadap Hasil Belajar IPA Siswa Kelas V SD Gugus 4 Baturiti. Universitas Pendidikan Ganesha.

Suwatra et.al. (2007). Modul Belajar Dan Pembelajaran. Universitas Pendidikan Ganesha.

Kurniasih, \& Sani. (2015). Ragam Pengembangan Model Pembelajaran Untuk Peningkatan Profesionalitas Guru. Kata Pena.

Pranata, P. A. (2013). Penerapan Model Pembelajaran Kooperatif Tipe Talking Stick Berbantuan Crosword Puzzle Untuk Meningkatkan Hasil Belajar Teknologi Informasi Dan Komunikasi (TIK) Siswa Kelas VII 2 SMP Negeri 2 Singaraja Tahun Ajaran 2012/2013. Universitas Pendidikan Ganesha.

Susanti, K. A. (2013). Pengaruh Penerapan Model Pembelajajaran Kooperatif Tipe Snowball Throwing Berbantuan Media Konkret Terhadap Hasil Belajar IPA Siswa Kelas V SD Gugus I Gusti Ngurah Rai Denpasar. Universitas Pendidikan Ganesha.

Aditya, K. M. (2013). Penerapan Metode Pembelajaran Kooperatif Tipe 
Snowball Throwing Untuk Meningkatkan Minat Dan Prestasi Belajar Instalasi Jaringan Komputer Siswa kelas XI TKJ1 SMK Negeri 2 Seririt. Universitas Pendidikan Ganesha.

Wirawan, D. N. (2013). Implementasi Model Pembelajaran Problem Based Learning (PBL) Pada Mata Pelajaran DKK Merakit PC Untuk Meningkatkan Aktivitas Dan Hasil Belajar Siswa Kelas X TKJ2 SMK Negeri 3 Singaraja Tahun Pelajaran 2012/2013. Universitas Pendidikan Ganesha.

Maindra, N. K. (2013). Penerapan Model Pembelajaran Kooperatif Tipe Means ENDS Analysis (MEA) Untuk meningkatkan Aktivitas Dan Hasil Belajar Siswa Mata Pelajaran TIK Kelas XII IPA 2 SMA Negeri 1 Kubutambahan Tahun Pelajaran 2012/2013. Universitas Pendidikan Ganesha. 